\title{
Whistleblowing on photovoltaic operations in Nigeria: panacea for sustainable development
}

\author{
Ugochukwu K. Okoro* (1) and Theo Chidiezie Chineke
}

\begin{abstract}
Background: There is no gainsaying about the importance of energy to the growth, development and socioeconomic well-being of any society. Photovoltaics (PV) have been identified not only as a means of meeting the energy needs of the Nigerian population but also as a tool in its national development. In this study, we reviewed the policy efforts of Nigeria in improving the renewable energy spread and the PV operations and utilization across the country.

Results: The technical audit of PV operations in Nigeria is evaluated using questionnaires administered in the 27 Local Government Areas in Imo State, as a case study. The component items in the latent variable scales of the audit have been tested for internal consistency using the Cronbach's alpha. The good variable scale "Appropriateness for energy need" indicated a dissenting perception, whereas the acceptable variable scales "Adequacy in energy efficiency" and "Sustainability of PV project" indicated significant confidence in their perceptions. The perception in the energy need, which is associated with the limitations in PV utilization, is perceived as wrongdoings.
\end{abstract}

Conclusions: The whistleblowing policy is advocated as a germane measure to reduce or stop these wrongdoings and improve PV utilization and spread in Nigeria.

Keywords: Photovoltaic, Renewable energy, Whistleblowing, Sustainable development, Nigeria

\section{Background}

Renewable energy is prescribed as the viable option in attaining the sustainable development goal of ensuring global access to affordable, reliable, sustainable and modern energy by mid-twenty-first century (SDG 2016). The earth's surface receives $1.4 \times 10^{5} \mathrm{TW}$ of solar power, but $3.6 \times 10^{4} \mathrm{TW}$ is usable, which is converted to electricity by concentrating solar thermal or photovoltaic (PV) technologies (Quaschning 2004; Hosenuzzaman et al. 2015). With about $10 \%$ of the world population without access to electricity having $30 \%$ of them in rural areas, it is anticipated that the decreasing cost of PV will boost investments in PV power plants owing to its ability to meet the growing energy demand yet reducing energy inputs to climate change, especially in reducing $\mathrm{CO}_{2}$ emissions (Asumadu-Sarkodie and Owusu 2016; Ren et al.

*Correspondence: uknac23@yahoo.com

Atmospheric Physics Group, Department of Physics, Imo State University, Owerri, Nigeria
2020). There have been about $60 \%$ of the world electricity generated by fossil fuels as of 2016, whereas $1.3 \%$ of global electricity is PV generated with about one-third of that capacity installed in China (Alsabbagh 2019). Until recently, the most popular application of this PV electricity has been in household electrification and water pumping driven by electric motors (Benlarbi et al. 2004; Dike et al. 2012; Singh 2019). Further declining price in PV coupled with the higher conversion efficiency suggests it will be the lowest cost option for future electricity supply, projected to account for $35 \%$ of the global electricity generation capacity by 2040 (Green 2016). This is evident as more PV power plants are installed globally, with indications that the PV module lifetime may be longer than the alleged 25 years hence improving the Levelized Cost of Energy (Breyer and Gerlach 2012). Indeed, energy needs will exacerbate as global urbanization is expected to increase, with Africa and Asia projecting at $56 \%$ by 2020 , whereas China, India and Nigeria account for $37 \%$ of the projection (Ebhota and Jen 2019). 
In Nigeria, PV utilization has significantly increased due to the population growth and the associated energy needs, whereas the country's energy consumption index has also significantly increased (Nwokocha et al. 2018). However, with the increasing population, several settlements are remotely located from the national grid (Tijani et al. 2014). It has been shown that the rural settlements, which represent $70 \%$ of the population, require 2324.5 Wh/day or $850.8 \mathrm{kWh} /$ year by each household for electrification (Adeoti et al. 2001; Ugwoke et al. 2020). Remedy to this challenge is not readily at the sight as the country has $12.5 \mathrm{GW}$ of installed electric power capacity, whereas less than one-third is operational as of 2015 and only about $15 \%$ is finally distributed to end-users (ERGP 2017). Nevertheless, there exist enormous potentials for PV power penetration as Fig. 1 shows the global solar radiation (Gh) on the optimally inclined plane across the country (Nwokocha et al. 2018). The effect of the insufficiently available energy on Nigeria socioeconomic status cannot be overemphasized. This has prompted most local business organizations to subscribe to the hybrid system, which comprises PV coupled to battery and generator, to sustain operations and profitability (Oparaku 2003; Adesanya and Pearce 2019). Noteworthy is that variability of PV power poses a challenge to its grid operation and utilization (Ming et al. 2017; Huang et al. 2018; Ebhota and Jen 2019).

The inadequate information about the technology, trust issues, lack of trained and technical skilled labour, public awareness and acceptance, adulterations, and absence of governing bodies and legislation are challenges in the penetration of PV technology (Mukai et al. 2011; Jones and Olsson 2017; Nwokocha et al. 2018; Alsabbagh 2019). Also, there exist challenges of the huge up-front capital cost for purchase and installation as well as the maintenance requirements (Dale and Benson 2013; Alsabbagh 2019). Gaps in grid parity, solar cell efficiency, smart grids security, resiliency and reliability, which may arise in the long-term from faults in transportation, installation and operations, still subsist (Breyer and Gerlach 2012; Smith et al. 2014; Tsanakas et al. 2016; Olowu et al. 2018). There is a complex and energy-intensive manufacturing process in producing the PV modules from silicon (Green 2016). The growing need for PV technologies has

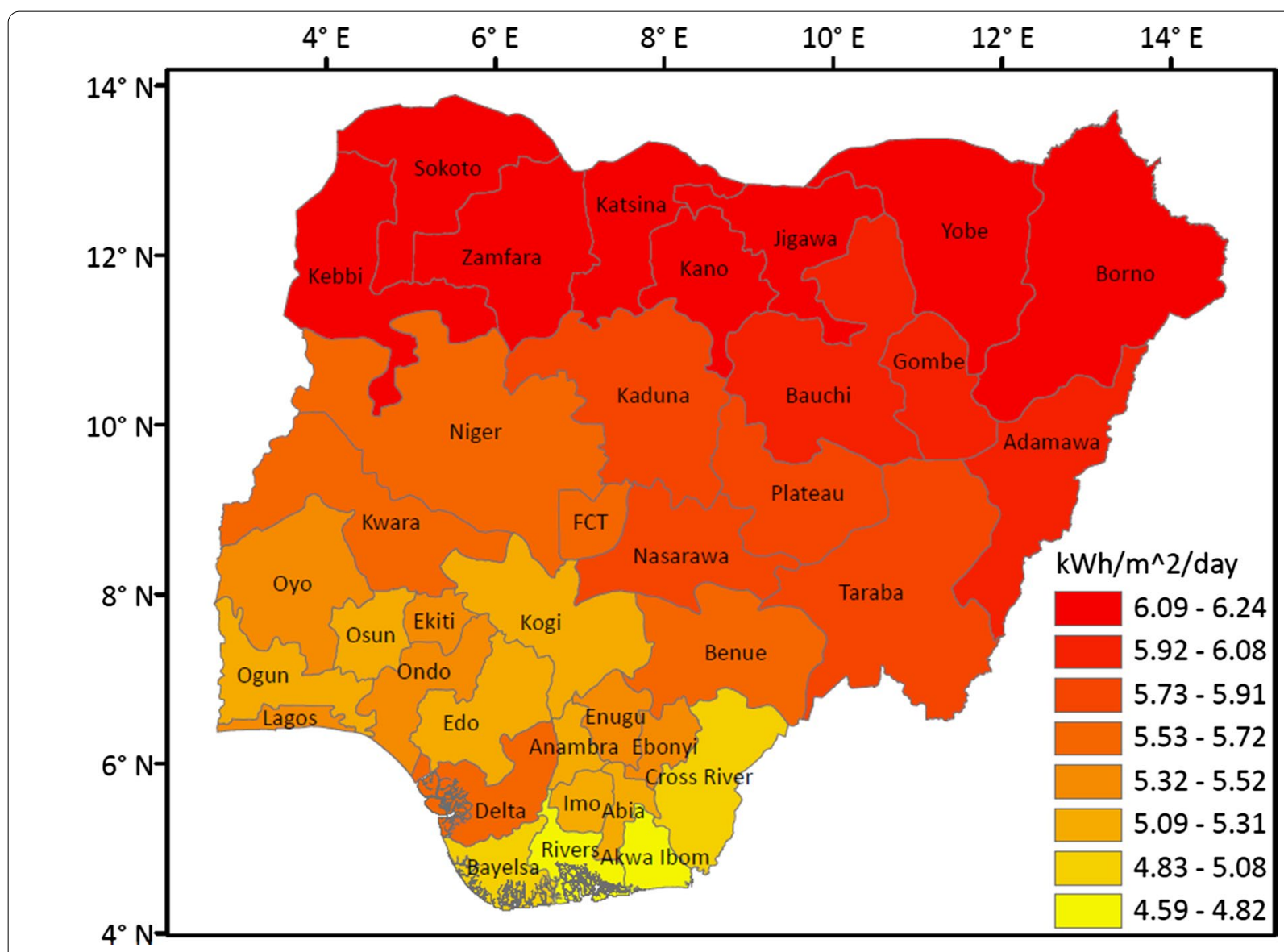

Fig. 1 Map of Nigeria indicating the global solar radiation (Gh) on the optimally inclined plane across the states (Nwokocha et al. 2018) 
increased demand for the mining industry with the attendant political, economic and environmental risks, especially in giving such metals a greater value, for instance, platinum, cobalt, lithium, vanadium and rare earth (Vikstrom 2020). Hence, there is the need for a reliable environmental licensing process (Hoffmann et al. 2019). On the other hand, competition for land in PV installation poses a grave threat to food production systems (Jones and Olsson 2017).

In this study, we aim to evaluate the operations of PV in Nigeria and the shortcomings, whereas we proffer whistleblowing policy as a viable measure to attaining its sustainable development. The remaining of this paper has been outlined as follows: second section presents Nigeria efforts towards PV penetration as an optional energy grid, evaluation and technical audit of PV operation in Nigeria is presented in third section, whistleblowing as the panacea to improving PV operations in Nigeria is presented in fourth section, and final section is Conclusion.

\section{Nigeria efforts towards PV penetration as an optional energy grid}

From the onset of Nigeria electricity generation in 1896 up till the last two decades, there has been no national existing model for financing and business ventures in that sector as obtained elsewhere (Ogueke et al. 2014; Adesanya and Pearce 2019). The National Integrated Power projects mandated to solely generate and supply grid electricity had been marked with corruption allegations (Diemuodeke and Oko 2013). Then, the national energy policy, the Electric Power Sector Reform act of 2005, births the framework for private sector participation in electricity generation, transmission and distribution (Enongene et al. 2019). The policy established a national energy generation target of $31 \%$ from all renewable energy sources by 2030 with solar PV delivering $76.36 \%$ of that for the States and Local Government Areas' (NREAP 2016; Enongene et al. 2019; Khodayar et al 2019). The intention is for Nigeria to produce $30,000 \mathrm{MW}$ of electric power by 2030 with $30 \%$ sourced from renewable energy termed "Electricity Vision 30:30:30" (NREAP 2016). But when compared with its ECOWAS peers, the 2030 targets seem quite remote (NREAP 2016).

There have been advancements in the large commercially available PV markets for off-grid PV rural electrification in developing countries (Breyer and Gerlach 2012). Hence, there have been efforts to source Green Equity Funds for the Nigeria national renewable energy targets (NREAP 2016). Indeed, diverse national energy and electricity reforms and policies expected to enhance the country's energy outlook have being implemented (Adesanya and Pearce 2019).
The Rural Electrification Strategy and Implementation Plan for the implementation of the Rural Electrification Agency, produced in 2016, is to expand the national access to electricity as swiftly as achievable in a cost resourceful approach. The Renewable Electricity Policy Guidelines of 2006 specifies the expansion plans for the renewable electricity mix up to 2016. The National Renewable Energy Master Plan of 2006, which was revised in 2012, provides a comprehensive structure for achieving the development and exploitation of renewable energy to $75 \%$ accessibility by 2025 . The National Renewable Energy and Energy Efficiency Policy of 2015 is to promote the renewable and energy efficiency capacity of the country by 2020 and limiting potential conflicts in the future. The Renewable Energy Feed-in Traffic Regulations of 2015 aims at supporting the national renewable target through private sector participation. The National Renewable Energy Action Plan from 2015 to 2030, developed to achieve the national target under the ECOWAS Renewable Energy Policy, portrays the nation's method of development and expansion to attain the regional $23 \%$ and $31 \%$ renewable energy target in 2020 and 2030, respectively. The Nigerian Bulk Electricity Trading Plc was established as the solely licensed issuer of Power Purchase Agreements, which in 2016 has already signed Memoranda of Understanding with solar energy firms to install and operate solar power stations in the country (Table 1).

Eventually, the success in these measures has brought about the proliferation of individual and non-individual off-grid solar PV projects that are either operational or in developmental stages at different locations throughout the country. But these PV projects are not exempted from the limitations and challenges that have been enumerated above. This has been evident in the persistent failures in most small and high profile PV projects as well as in the abandoned PV projects littered at various locations (Dike et al. 2017; Nwokocha et al. 2018).

\section{Methods}

\section{Technical audit of PV operation in Nigeria}

A technical audit was carried out on the public PV power projects sited at the administrative headquarters in the 27 Local Government Areas of Imo State, as the reference case. Imo State is one of the administrative federating States of Nigeria, whereas its choice was based on its proximity and the availability of resources. Data were obtained from questionnaires administered to 20 respondents that were simple randomly selected by lottery method. The sample population was drawn from the strata of 10 males and 10 females, respectively that comprised of 5 older adults and 5 younger adults, respectively. The response rate of $100 \%$ was attained using a 
Table 1 Proposed solar power plants based on Nigerian Bulk Electricity Trading Plc signed Power Purchase Agreements (SWE 2016; Vanguard 2016; Bloomberg 2017; Nation 2017)

\begin{tabular}{|c|c|c|c|}
\hline $\mathrm{S} / \mathrm{N}$ & Location/ State & Capacity (MW) & Solar Project Partner \\
\hline 1 & Adamawa & 500 & LTI ReEnergy/ Nigus \\
\hline 2 & Bauchi & 100 & Nigeria Solar Capital Partners \\
\hline 3 & Borno & 100 & General Electric \\
\hline 4 & Enugu & 100 & GreenWish Partner \\
\hline 5 & Federal Capital Territory (FCT) & 100 & LR Aaron Power \\
\hline 6 & Jigawa & 50 & GreenWish Partner \\
\hline 7 & Jigawa & 80 & Nova Scotia/CDIL/Scatec Solar \\
\hline 8 & Jigawa & 50 & Oriental Renewable Solutions \\
\hline 9 & Kaduna & 50 & GreenWish Partner \\
\hline 10 & Kaduna & 50 & En Africa \\
\hline 11 & Kaduna & 50 & Quaint Abiba Power \\
\hline 12 & Kaduna & 100 & Anjeed Innova Group \\
\hline 13 & Kano & 100 & Dangote/Black Rhino Group \\
\hline 14 & Katsina & 75 & Pan Africa Solar \\
\hline 15 & Katsina & 100 & Nova Solar 5 Farm \\
\hline 16 & Kebbi & 100 & General Electric \\
\hline 17 & Kogi & 100 & Middle Band Solar One \\
\hline 18 & Nasarawa & 50 & Afrinergia Power \\
\hline 19 & Nasarawa & 100 & Motir Dusable \\
\hline 20 & Nasarawa & 100 & General Electric \\
\hline 21 & Niger & 100 & General Electric \\
\hline 22 & Plateau & 70 & CT Cosmos \\
\hline 23 & Sokoto & 100 & KVK Power \\
\hline 24 & Taraba & 100 & General Electric \\
\hline Total capacity & & 2425 & \\
\hline
\end{tabular}

drop-off/pick-up survey method, thus summing a total of 540 respondents (Olson-Hazboun et al. 2016). The component items from the questionnaire were designed to address the latent variables outlined in Table 2, which demonstrates the perception of the population to the PV projects.

\section{Data analysis}

The items of each latent variable (Table 2) were tested for reliability in their internal consistency using the Cronbach's alpha method (Taber 2018). The interrelationship among the percentage agreement in responses to the items and across the 27 locations, for each respective variable scale, is evaluated using the single-factor analysis of variance (ANOVA) (Nwokocha et al. 2018).

\section{Results}

The reliability test score indicates that the items in the variable "Appropriateness for energy need" has good consistency among themselves and with the overall instrument. The variables "Adequacy in energy efficiency" and "Sustainability of PV project" have acceptable consistency among themselves and with the overall instrument, respectively. In the variable "Appropriateness for energy need", the p-value indicates that there were dissenting perceptions (Table 3). This is likely as there has been a significantly increasing demand for electric energy due to modernization and urbanization (Chineke et al. 2010). Also, the failure of the PV powered street lights and water borehole systems create doubts of PV meeting the actual non-metered home energy needs. The poor spread of the projects is also indicative of this perception. Another concern is the amount of land area that would be required to meet these energy needs.

The p-value on "Adequacy in energy efficiency" indicates the confidence in the functional PV projects' performances (Table 4). This is evident as the projects function effortlessly and efficiently, lighting the streets at night and providing clean water from the water pumps. They do not see any refuelling for this to go on, and the infrastructures do not need frequent servicing. Similarly, the p-value on "Sustainability of PV project" indicates the confidence in the sustenance of the PV projects for a longer period (Table 5). This is derived from the duration 
Table 2 Latent variable scales in the PV projects Technical audit with their respective reliability and component items

\begin{tabular}{|c|c|c|}
\hline Latent variable scales & $\begin{array}{l}\text { Cronbach's } \\
\text { alpha (reliability } \\
\text { test) }\end{array}$ & Component items \\
\hline Appropriateness for energy need & 0.82 & $\begin{array}{l}\text { 1. Solar project is initiated at the appropriate time. (4-point Likert scale from "Strongly agree" to } \\
\text { "Strongly disagree") } \\
\text { 2. Location of the solar project is appropriate and feasible. (4-point Likert scale from "Strongly } \\
\text { agree" to "Strongly disagree") } \\
\text { 3. Area coverage of the solar project is appropriate. (4-point Likert scale from "Strongly agree" to } \\
\text { "Strongly disagree") } \\
\text { 4. Solar project serves the purpose for which it is provided. (4-point Likert scale from "Strongly } \\
\text { agree" to "Strongly disagree") }\end{array}$ \\
\hline Adequacy in energy efficiency & 0.74 & $\begin{array}{l}\text { 1. Energy output of the solar project satisfies the purpose for installation. (4-point Likert scale } \\
\text { from "Strongly agree" to "Strongly disagree") } \\
\text { 2. Solar project functions efficiently and when it fails repairs come immediately. (4-point Likert } \\
\text { scale from "Strongly agree" to "Strongly disagree") } \\
\text { 3. Solar project performance is the same with conventional energy powered options. (4-point } \\
\text { Likert scale from "Strongly agree" to "Strongly disagree") } \\
\text { 4. Experts should mount and maintain such solar projects. (4-point Likert scale from "Strongly } \\
\text { agree" to "Strongly disagree") }\end{array}$ \\
\hline Sustainability of PV project & 0.70 & $\begin{array}{l}\text { 1. There is adequate security provided for the solar project. (4-point Likert scale from "Strongly } \\
\text { agree" to "Strongly disagree") } \\
\text { 2. There have been varying discomforts associated with the installed solar project. (4-point Likert } \\
\text { scale from "Strongly agree" to "Strongly disagree") } \\
\text { 3. Solar project is expected to have a long life span. (4-point Likert scale from "Strongly agree" to } \\
\text { "Strongly disagree") } \\
\text { 4. More installations of such solar project are encouraged. (4-point Likert scale from "Strongly } \\
\text { agree" to "Strongly disagree") }\end{array}$ \\
\hline
\end{tabular}

Table 3 Single-factor ANOVA on the percentage agreement of the items in the variable scale "Appropriateness for energy need" with $\alpha=0.05$

\begin{tabular}{|c|c|c|c|c|c|c|}
\hline Source of variation & SS & $d f$ & MS & $F$ & P-value & F crit \\
\hline Between groups & 9328.24 & 26 & 358.7785 & 2.2849 & 0.0026 & 1.6327 \\
\hline Within groups & $12,718.75$ & 81 & 157.0216 & & & \\
\hline Total & $22,046.99$ & 107 & & & & \\
\hline
\end{tabular}

Table 4 Single-factor ANOVA on the percentage agreement of the items in the variable scale "Adequacy in energy efficiency" with $\alpha=0.05$

\begin{tabular}{|c|c|c|c|c|c|c|}
\hline Source of variation & SS & $d f$ & MS & $\mathrm{F}$ & P-value & F crit \\
\hline Between groups & 3004.17 & 26 & 115.5449 & 0.9209 & 0.5794 & 1.6327 \\
\hline Within groups & $10,162.50$ & 81 & 125.4630 & & & \\
\hline Total & $13,166.67$ & 107 & & & & \\
\hline
\end{tabular}

Table 5 Single-factor ANOVA on the percentage agreement of the items in the variable scale "Sustainability of PV project" with $\alpha=0.05$

\begin{tabular}{|c|c|c|c|c|c|c|}
\hline Source of variation & SS & $d f$ & MS & $\mathrm{F}$ & P-value & F crit \\
\hline Between groups & 3241.67 & 26 & 124.6795 & 0.7302 & 0.8158 & 1.6327 \\
\hline Within groups & $13,831.25$ & 81 & 170.7562 & & & \\
\hline Total & $17,072.92$ & 107 & & & & \\
\hline
\end{tabular}


of completion and operation of the PV projects. Also is the safety of the functional projects from destruction and vandalism within their localities. There is also the performance improvement in some of the PV projects and in their quality.

\section{Discussion}

Certainly, investors, the government and even the citizens incur potential costs and losses when PV installations go wrong or wrongdoings are perceived in its operations. These wrongdoings may be involuntary in some cases. Whistleblowing is imperative to reduce these kinds of costs or losses. Such wrongdoings, as enumerated in the previous section, will be defined by the whistleblowers who are motivated by incentives, pressure, opportunity or rationalization, and may respond differently to the situations; however, with the rationale for it to be stopped or corrected (Latan et al. 2019; Smaili and Arroyo 2019). It is vital to see the whistleblower being a concerned citizen or of strong moral character rather than erroneously as a disgruntled or vindictive individual or group (Watts and Buckley 2017; Smaili and Arroyo 2019).

Since the wrongdoings vary, it is expected that the motivations for whistleblowing should vary too, but the fundamental motive should be to improve the deployment of PV to improve energy availability and accessibility in Nigeria for sustainable development. The issue then becomes what brings about these kinds of wrongdoings, when, how and why they do occur (Near and Miceli 2016)?

Indeed, the whistleblowing in the PV operations should be in encouraging and prioritizing grid parity in per unit energy cost, for its sustainability (Zheng and Kammen 2014). In the funding gaps, there should be financial support policies such as a third-party financing option for both residential and commercial projects (Alsabbagh 2019; dos Santos Carstens and da Cunha 2019). For the shortage of skilled professionals, the training and retraining of technicians and artisans being issued verifiable certifications are vital (Mukai et al. 2011; Akinyele et al. 2019; dos Santos Carstens and da Cunha 2019). In the PV technologies deployed, incorporating recent trends rather than obsolete technologies should be prioritized such as the use of recent conversion efficient generation of PV cells, the use of bifacial PV modules, incorporating Phase Change Materials in projects to enhance cell efficiency of PV modules and incorporating solar trackers in the PV installations (Smith et al. 2014; Njoku 2016; Hussin et al. 2017; Liang et al. 2018; Akinyele et al. 2019; dos Santos Carstens and da Cunha 2019).

With regard to the cost and availability of components, local manufacturing should be supported for components mined locally bearing in mind the global technology trend and local environmental regulations to optimize PV operations (Hoffmann et al. 2019; Vikstrom 2020). For location spread and area coverage, off-grid technologies with scales of households to community should be encouraged and prioritized, with incentives such as feedin taxes and tax credits, especially as PV project lead time is the shortest for any power generation technology (Hancevic et al. 2017; Jones and Olsson 2017; Ohunakin et al. 2018; Khodayar et al. 2019). In the scarcity of land for the PV projects, the use of rooftops should be encouraged and prioritized instead of agricultural land (Jones and Olsson 2017; Enongene et al. 2019). And in the city layout of the PV locations, incorporating the aesthetic perception of PV technologies in the architectural and urban planning should be supported (Sánchez-Pantoja et al. 2018). For utility energy losses, the incorporation of smart inverters to monitor, react to and adjust their output should be prioritized (Obi and Bass 2016). For the quality and standards of PV materials, penalties such as imprisonment and fines should be imposed on adulterators (Nwokocha et al. 2018).

However, there are challenges of whistleblowing such as harassment and retaliation against the whistleblower, the strength of evidence against the wrongdoing and how supportive the responsible agencies are (Yang and Yang 2019). Hence, the Nigerian government or policymakers should assign a department, agency or commission that strengthens punishments for PV operations wrongdoers and make whistleblowing an important channel to the PV energy penetration and sustainability. Public participation should form an indispensable part of whistleblowing especially with the comparative cost and anonymity offered by the rapid development of the Internet and smartphones (Watts and Buckley 2017).

\section{Conclusions}

The energy poverty in Nigeria has adversely affected the country's desire to attain sustainable development goals and improve the socio-economic status of its citizens. Notwithstanding the numerous renewable energy policy efforts in Nigeria, there is yet to be the desired renewable energy coverage and utilization across the country. The PV energy has been identified to be a more suitable means of attaining the energy spread and in a shorter time span. However, PV operations have their attendant limitations, which could be intentional or unintentional. The technical audit of the PV projects operation in Nigeria using the internally consistent latent variable scales reveals a dissenting perception of its appropriateness to their energy needs. However, the PV projects energy efficiency and their sustainability show significant acceptance in the audit. 
The perception of the energy need is associated with the limitations in PV energy utilization. Whistleblowing is advocated as a panacea to improving the operations of PV energy in Nigeria, whereas the indicators to the perceived wrongdoings in the PV utilization will be reduced or stopped if the policy is adequately supported.

\section{Abbreviations}

ANOVA: Analysis of variance; ECOWAS: Economic Community of West African States; Gh: Global solar radiation; PV: Photovoltaics; TW: Tera Watt.

\section{Acknowledgements}

TCC appreciates the TETFund IBR intervention from Imo State University, Owerri, Nigeria. The authors are grateful to the research team as well as the anonymous reviewers.

\section{Authors' contributions}

UKO and TCC carried out the research conception and design, data acquisition, analysis and interpretation of data. Both authors drafted the manuscript. All authors discussed the results and commented on the manuscript. All authors read and approved the final manuscript.

\section{Funding}

This research is financially supported by TETFund Institutional Based Research project intervention of Imo State University, Owerri, Nigeria.

\section{Availability of data and material}

All the data generated or analysed during the study are included in this published article.

\section{Declarations}

Ethics approval and consent to participate

Not applicable.

\section{Consent for publication}

Not applicable.

\section{Competing interests}

The authors declare that they have no competing interests.

Received: 20 April 2021 Accepted: 26 July 2021

Published online: 04 August 2021

\section{References}

Adeoti O, Oyewole BA, Adegboyega TD (2001) Solar photovoltaic-based home electrification system for rural development in Nigeria: domestic load assessment. Renew Energy 24:155-161. https://doi.org/10.1016/s0960$1481(00) 00188-9$

Adesanya AA, Pearce JM (2019) Economic viability of captive off-grid solar photovoltaic and diesel hybrid energy systems for the Nigerian private sector. Renew Sustain Energy Rev 114:109348. https://doi.org/10.1016/j. rser.2019.109348

Akinyele D, Babatunde O, Monyei C, Olatomiwa L, Okediji A, Ighravwe D, Abiodun O, Onasanya M, Temikotan K (2019) Possibility of solar thermal power generation technologies in Nigeria: challenges and policy directions. Renew Energy Focus 29:24-41. https://doi.org/10.1016/j.ref.2019.02.002

Alsabbagh M (2019) Public perception toward residential solar panels in Bahrain. Energy Rep 5:253-261. https://doi.org/10.1016/j.egyr.2019.02.002

Asumadu-Sarkodie S, Owusu PA (2016) The potential and economic viability of solar photovoltaic power in Ghana. Energy Sour Part A Recov Util Environ Effects 38(5):709-716. https://doi.org/10.1080/15567036.2015.1122682

Benlarbi K, Mokrani L, Nait-Said MS (2004) A fuzzy global efficiency optimization of a photovoltaic water pumping system. Sol Energy 77:203-216. https://doi.org/10.1016/j.solener.2004.03.025
Bloomberg (2017) GreenWish to Invest USD 280 million in Nigeria Solar plant. Bloomberg Market, March 2017. https://www.renewableenergyworld. com/articles/2017/03/greenwish-to-invest-280-million-in-nigeria-solarplants.html

Breyer C, Gerlach A (2012) Global overview on grid-parity. Prog Photovolt Res Appl. https://doi.org/10.1002/pip.1254

Chineke TC, Nwofor OK, Okoro UK (2010) Optimal benefits of utilizing renewable energy technologies in Nigeria and the CIBS quadrangle - a review. Bayero J Pure Appl Sci 3(1):142-146. https://doi.org/10.4314/bajopas.v3i1. 58752

Dale M, Benson SM (2013) Energy balance of the global photovoltaic (PV) industry -is the PV industry a net electricity producer? Environ Sci Technol 47:3482-3489. https://doi.org/10.1021/es3038824

Diemuodeke EO, Oko COC (2013) Optimum configuration and design of a photovoltaic-diesel-battery hybrid energy system for a facility in University of Port Harcourt, Nigeria. Int J Ambient Energy. https://doi.org/10. 1080/01430750.2013.866906

Dike VN, Chineke TC, Nwofor OK, Okoro UK (2012) Optimal angles for harvesting solar electricity in some African cities. Renew Energy 39:433-439. https://doi.org/10.1016/j.renene.2011.08.001

Dike VN, Opara-Nestor CA, Amaechi JN, Dike DO, Chineke TC (2017) Solar PV System Utilization in Nigeria: Failures and Possible Solutions. Pacific Journal of Science and Technology 18(1):51-61

dos Santos Carstens DD, da Cunha SK (2019) Challenges and opportunities for the growth of solar photovoltaic energy in Brazil. Energy Policy 125:396-404. https://doi.org/10.1016/j.enpol.2018.10.063

Ebhota WS, Jen TC (2019) Fossil fuels environmental challenges and the role of solar photovoltaic technology advances in fast tracking hybrid renewable energy system. Int J Precis Eng Manuf Green Technol. https://doi.org/10. 1007/s40684-019-00101-9

Enongene KE, Abanda FH, Otene IJJ, Obi SI, Okafor C (2019) The potential of solar photovoltaic systems for residential homes in Lagos city of Nigeria. J Environ Manag 244:247-256. https://doi.org/10.1016/j.jenvman.2019. 04.039

ERGP (2017) Federal Republic of Nigeria Economic Recovery and Growth Plan 2017-2020. Ministry of Budget and National Planning, Nigeria, pp 140

Green MA (2016) Commercial progress and challenges for photovoltaics. Nat Energy. https://doi.org/10.1038/NENERGY.2015.15

Hancevic PI, Nuñez HM, Rosellon J (2017) Distributed photovoltaic power generation: possibilities, benefits, and challenges for a widespread application in the Mexican residential sector. Energy Policy 110:478-489. https://doi.org/10.1016/j.enpol.2017.08.046

Hoffmann AS, de Carvalho GH, Cardoso RAFJr, (2019) Environmental licensing challenges for the implementation of photovoltaic solar energy projects in Brazil RAF. Energy Policy 132:1143-1154. https://doi.org/10.1016/j. enpol.2019.07.002

Hosenuzzaman M, Rahim NA, Selvara J, Hasanuzzaman M, Malek ABMA, Nahar A (2015) Global prospects, progress, policies, and environmental impact of solar photovoltaic power generation. Renew Sustain Energy Rev 41:284-297. https://doi.org/10.1016/j.rser.2014.08.046

Huang C, Cao L, Peng N, Li S, Zhang J, Wang L, Luo X, Wang J-H (2018) Day-ahead forecasting of hourly photovoltaic power based on robust multilayer perception. Sustainability 10:4863. https://doi.org/10.3390/ su10124863

Hussin F, Issabayeva G, Aroua MK (2017) Solar photovoltaic applications: opportunities and challenges. Rev Chem Eng. https://doi.org/10.1515/ revce-2016-0058

Jones LE, Olsson G (2017) Solar photovoltaic and wind energy providing water. Global Chall 1:1600022. https://doi.org/10.1002/gch2.201600022

Khodayar ME, Feizi MR, Vafamehr A (2019) Solar photovoltaic generation: benefits and operation challenges in distribution networks. Electr J 32:50-57. https://doi.org/10.1016/j.tej.2019.03.004

Latan H, Jabbour CJC, Jabbour ABL (2019) 'Whistleblowing triangle': framework and empirical evidence. J Bus Ethics 160(1):189-204. https://doi.org/10. 1007/s10551-018-3862-x

Liang TS, Poh D, Pravettoni M (2018) Challenges in the pre-normative characterization of bifacial photovoltaic modules. Energy Procedia 150:66-73. https://doi.org/10.1016/j.egypro.2018.09.006

Ming B, Liu P, Guo S, Zhang X, Feng M, Wang X (2017) Optimizing utilityscale photovoltaic power generation for integration into a hydropower 
reservoir by incorporating long- and short-term operational decisions. Appl Energy 204:432-445. https://doi.org/10.1016/j.apenergy.2017.07.046

Mukai T, Kawamoto S, Ueda Y, Saijo M, Abe N (2011) Residential PV system users' perception of profitability, reliability, and failure risk: an empirical survey in a local Japanese municipality. Energy Policy 39:5440-5448 https://doi.org/10.1016/j.enpol.2011.05.019

Nation (2017) Kano, Dangote, Rhino Group sign \$150m solar power project. The Nation Nigeria, 10 August 2017. https://thenationonlineng.net/kanodangote-rhino-group-sign-150m-solar-power-project/.

Near JP, Miceli MP (2016) After the wrongdoing: what managers should know about whistleblowing. Bus Horiz 59:105-114. https://doi.org/10.1016/j. bushor.2015.09.007

Njoku HO (2016) Upper-limit solar photovoltaic power generation: estimates for 2-axis tracking collectors in Nigeria. Energy 95:504-516. https://doi. org/10.1016/j.energy.2015.11.078

NREAP (2016) National Renewable Energy Action Plans (NREAP) (2015-2030) First Version. Inter-Ministerial Committee on Renewable Energy and Energy Efficiency (ICREEE). National Council on Power (NACOP) July 14, 2016. Pp 82

Nwokocha CO, Okoro UK, Usoh Cl (2018) Photovoltaics in Nigeria-awareness, attitude and expected benefit based on a qualitative survey across regions. Renew Energy 116:176-182. https://doi.org/10.1016/j.renene. 2017.09.070

Obi M, Bass R (2016) Trends and challenges of grid-connected photovoltaic systems - a review. Renew Sustain Energy Rev 58:1082-1094. https://doi. org/10.1016/j.rser.2015.12.289

Ogueke NV, Ikpamezie II, Anyanwu EE (2014) The potential of a small hydro/ photovoltaic hybrid system for electricity generation in FUTO, Nigeria. Int J Ambient Energy. https://doi.org/10.1080/01430750.2014.952841

Ohunakin OS, Adaramola MS, Oyewola OM, Fagbenle RO, Adelekan DS, Gill J, Abam FI (2018) Photovoltaic performance prediction in Northern Nigeria using generated typical meteorological year dataset. Afr J Sci Technol Innov Dev. https://doi.org/10.1080/20421338.2018.1511280

Olowu TO, Sundararajan A, Moghaddami M, Sarwat Al (2018) Future challenges and mitigation methods for high photovoltaic penetration: a survey. Energies 11:1782. https://doi.org/10.3390/en11071782

Olson-Hazboun SK, Krannich RS, Robertson PG (2016) Public views on renewable energy in the Rocky Mountain region of the United States: distinct attitudes, exposure, and other key predictors of wind energy. Energy Res Soc Sci 21:167-179. https://doi.org/10.1016/j.erss.2016.07.002

Oparaku OU (2003) Rural area power supply in Nigeria: a cost comparison of the photovoltaic, diesel/gasoline generator and grid utility options. Renewable Energy 28:2089-2098. https://doi.org/10.1016/S09601481(03)00009-0

Quaschning V (2004) Technical and economical system comparison of photovoltaic and concentrating solar thermal power systems depending on annual global irradiation. Sol Energy 77:171-178. https://doi.org/10. 1016/j.solener.2004.04.011

Ren FR, Tian Z, Liu J, Shen YT (2020) Analysis of CO2 emission reduction contribution and efficiency of China's solar photovoltaic industry: based on input-output perspective. Energy 199:1 17493. https://doi.org/10.1016/J energy.2020.117493

Sánchez-Pantoja N, Vidal R, Pastor MC (2018) Aesthetic perception of photovoltaic integration within new proposals for ecological architecture. Sustain Cities Soc 39:203-214. https://doi.org/10.1016/.jscs.2018.02.027
SDG (2016) The sustainable development goals report. United Nations, New York

Singh V (2019) Influence of manually adjustable photovoltaic array on the performance of water pumping systems. Global Chall 3:1900009. https:// doi.org/10.1002/gch2.201900009

Smaili N, Arroyo P (2019) Categorization of whistleblowers using the whistleblowing triangle. J Bus Ethics 157(1):95-117. https://doi.org/10.1007/ s10551-017-3663-7

Smith CJ, Forster PM, Crook R (2014) Global analysis of photovoltaic energy output enhanced by phase change material cooling. Appl Energy 126:21-28. https://doi.org/10.1016/j.apenergy.2014.03.083

SWE (2016) The platform for Renewable Energies. 500 MW solar power plants are to be built in Nigeria. Sun and Wind Energy, December 2016. http:// www.sunwindenergy.com/photovoltaics/500-mw-solar-power-plants-tobuilt-nigeria.

Taber KS (2018) The use of Cronbach's alpha when developing and reporting research instruments in science education. Res Sci Educ 48:1273-1296. https://doi.org/10.1007/s11165-016-9602-2

Tijani HO, Tan CW, Bashir N (2014) Techno-economic analysis of hybrid photovoltaic/diesel/battery off-grid system in northern Nigeria. J Renew Sustain Energy 6:033103. https://doi.org/10.1063/1.4873122

Tsanakas JA, Ha L, Buerhop C (2016) Faults and infrared thermographic diagnosis in operating c-Si photovoltaic modules: a review of research and future challenges. Renew Sustain Energy Rev 62:695-709. https://doi.org/ 10.1016/j.rser.2016.04.079

Ugwoke B, Gershon O, Becchio C, Corgnati SP, Leone P (2020) A review of Nigerian energy access studies: the story told so far. Renew Sustain Energy Rev 120:109646. https://doi.org/10.1016/j.rser.2019.109646

Vanguard (2016) Solar Power Development: Investors commit USD 2.5 billion into 14 projects. Vanguard Newspaper Nigeria, 22 July 2016. https://www. vanguardngr.com/2016/07/solar-power-devt-investors-commit-2-5bn14-projects/

Vikstrom H (2020) Risk or opportunity? The extractive industries'response to critical metals in renewable energy technologies, 1980-2014. Extract Ind Soc. https://doi.org/10.1016/..exis.2020.01.004

Watts LL, Buckley MR (2017) A dual-processing model of moral whistleblowing in organizations. J Bus Ethics 146(3):669-683. https://doi.org/10.1007/ s10551-015-2913-9

Yang Y, Yang W (2019) Does whistleblowing work for air pollution control in China? A study based on three-party evolutionary game model under incomplete information. Sustainability 11:324. https://doi.org/10.3390/ su11020324

Zheng C, Kammen DM (2014) An innovation-focused roadmap for a sustainable global photovoltaic industry. Energy Policy. https://doi.org/10.1016/j. enpol.2013.12.006

\section{Publisher's Note}

Springer Nature remains neutral with regard to jurisdictional claims in published maps and institutional affiliations.

\section{Submit your manuscript to a SpringerOpen ${ }^{\circ}$ journal and benefit from:}

- Convenient online submission

- Rigorous peer review

- Open access: articles freely available online

- High visibility within the field

- Retaining the copyright to your article

Submit your next manuscript at $\boldsymbol{\nabla}$ springeropen.com 